\title{
Growth Sectors in Morocco and Investment Potential: A Quantitative Analysis
}

\author{
Pascal Pouya ${ }^{1}$, Aziz Khayati $^{1} \&$ Kamal Chatouane ${ }^{1}$ \\ ${ }^{1}$ Faculty of Law-Sale, University Mohammed V of Rabat, Morocco \\ Correspondence: Pascal Pouya, Faculty of Law-Sale, University Mohammed V of Rabat, Morocco. E-mail: \\ contact@starsgroupconsulting.com
}

Received: July 7, 2021

doi:10.5539/ijef.v13n10p54
Accepted: September 3, 2021

Online Published: September 5, 2021

\begin{abstract}
During the 1990s Morocco implemented a series of major institutional and economic reforms that made the country politically stable and helped it to withstand the destabilizing effects of the Arab Spring. Political reforms resulted in the adoption of a new constitution in 2011, was followed by initiatives to improve justice, public administration, the fight against corruption, and to strengthen governance, transparency, and ethics in public life. The country also embarked on a regionalization of public policies and decentralization of administration to ensure an integrated and durable regional development. This reform momentum was further emphasized by the King of Morocco when in his 2019 throne speech he stressed that “... the stake is thus to rebuild a strong and competitive economy, by encouraging the private initiative, while launching new productive investment plans and by creating new job opportunities..."

During two last decades Morocco recorded relatively solid economic and social results due to significant public investments and structural reforms aiming to: (i) stabilize the macroeconomic framework by reducing domestic and external vulnerabilities, in particular through the gradual suppression of subsidies for energy products and some foodstuffs; (ii) improve the framework of management of public finance through the adoption of a new Organic Law of Finance in 2015; and (iii) support the diversification and the competitiveness of the national economy. Morocco also reinforced its sectorial policies through plans for sector development aiming at enhancing the economic growth potential and the creation of jobs, including in the manufacturing sectors with significant added value in sectors such as the automotive, aeronautics and pharmaceutical products.

The Moroccan economy has demonstrated an appreciable resilience in the face of an international context characterized by a succession of crises. The rate of growth of real GDP improved on average annually from $3.1 \%$ during the 1990 s to nearly $4.2 \%$ on average annually between 2007 and 2018, sustained by the tertiary sector's dynamism which posted an increase in its value added of $4.2 \%$, contributing of 2.1 points in the GDP (Figure 1).

The secondary sector also showed a similar tendency with a $3.3 \%$ increase in added value, carrying with it 0.9 percentage points contribution in economic growth, while the primary sector added value grew by $4.4 \%$ for a contribution to the growth of the GDP of 0.6 point (DEPF, 2019).
\end{abstract}

Keywords: investment, input-output, growth

\section{General View of Moroccan Economy}

\subsection{Introduce the Problem}

Overall, the two last decades were marked by the rise of employment in the construction and the tertiary sector at the expense of the other sectors, leading to the belief that the Moroccan economy is suffering from "Dutch Disease" (World Bank, 1999), essentially its public component, with a contribution of 1.2 points (General State Budget and State Owned Enterprises (SOEs). 




Figure 1. A strong volatility of the GDP and its components, 2007-2018

The favorable performance of economic activity is also driven by vigorous domestic demand, in particular household consumption demand which remains, between 2007 at 2018, by far the main growth driver with a contribution of 2.4 points in GDP, followed by Gross Fixed Capital Formation (GFCF), essentially its public component, with a contribution of 1.2 points in GDP (General State Budget and State Owned Enterprises (SOEs). On the contrary external demand has been running in the opposite direction as the contribution of net foreign trade was negative, withdrawing 0.3 point of GDP and this, despite an increase of exports of $6 \%$ between the periods 2007-2018. This situation reflects strong import propensity and the external dependency of the national economy, with a tripling of the value of imports since the beginning of the year 2007. State imports of equipment aggravated the budget deficit which reached an average of $4 \%$ between 2007-2018. It is to say that the "twin deficits" widened but remained sustainable.

During the last ten years the supply side of the economy not only grown moderately as it was also quite volatile slowing down over the last three years and not being transformative enough. As a result, it has not been strong enough to generate sufficient employment in the formal economy.

The ongoing Covid-19 pandemic has triggered an abrupt recession, the first since 1995 . The economy is likely to undergo the double impact of the economic internal and external shocks like other countries.

\subsection{Limited Impact of the Investment on the Economic Activity}

While domestic demand has been the principal engine of economic growth for many years, the impact of investment effort should not be ignored, even if limited. Total Investment reached 33.5\% of the GDP in 2018, which is quite high in comparison with similar income MENA countries. This has been on account of the large public infrastructure projects (such as highways, airports and the Tangier-Med port).

However Morocco suffers from weak investment effectiveness for those projects carried out by the government and SOEs (HCP, 2016) (Note 1). As a result it has not led yet to significant gains of productivity and its repercussions on the Moroccan economy in terms of growth and employment is still weak.

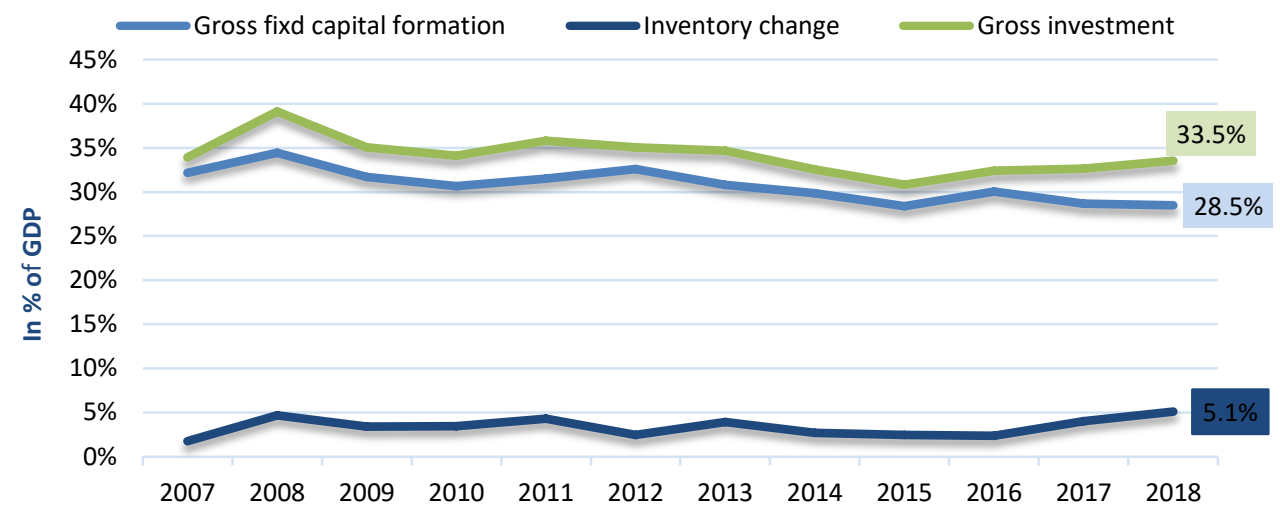

Figure 2. Stagnation of the rate of investment on a raised level, 2007-2018 
Employment creations is concentrated in the sectors where the productivity gain is weak. In the end of 2018, the Moroccan economy generated approximately 7.1 million jobs outside agriculture. More than the one quarter of this number (2.8 million) was created in two sectors only: the building industry and trade. Thus, the incremental capital-output ratio (ICOR) (Note 2) is high in comparison with other countries like Argentina, Chili, Malaysia, Poland, South Africa, Spain and Turkey (HCP, 2016) having lower or comparable rates of investment. In total, the Moroccan economy fails to gain significantly in efficiency in spite of the structural reforms. Morocco would significantly improve its labor productivity if it were to improve the marginal return on capital.

Two principal reasons lie behind weak investment efficiency in Morocco: (i) the concentration of investments, by eviction effect, in infrastructure, in the non-exchangeable goods and services sectors (protected sectors against competition), and in the real estate as expense of the productive sectors, and (ii) for investments oriented toward the productive sectors, the weakness is due to a lack of competitiveness of the labor factor in relation to Morocco's competitors (resulting from a relatively higher cost of living) and the weakness of human capital (CESE, 2019).

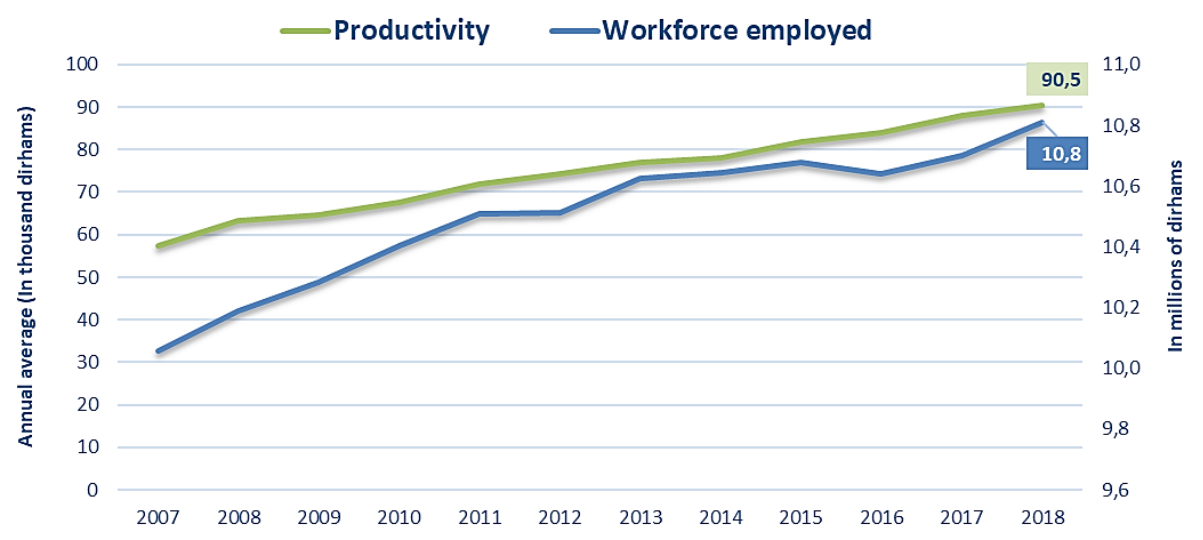

Figure 3. Trends in labor productivity and employment 2007-2018

In the coming years, the political scene will be defined by the legislative elections of 2021 . The evolution of the current social context of Morocco will depend on the effectiveness of new development policies, including the increase in the social expenditures in the 2021 and 2022 budget, the king's call to review the development model of Morocco, the launching of the third phase of the National Initiative of Human Development and an increased attention on the social and economic integration of the young people. Also, within the framework of the 2021 budget, a special account entitled "Mohammed VI Fund for Investment" was created and endowed with 15 billion dirhams.

\section{Sectors Scanning}

In 2000 Morocco launched significant institutional and economic reforms founded on strategies to correct the market failures in important sectors of the economy. These strategies included tax exemptions and other financial incentives, facilitation of access to land and simplification of the administrative procedures, and launching of large public infrastructure projects, all of which combined to create new dynamics for investments in strategic sectors such as agriculture, industry and energy.

These efforts touched all many sectors: The plan Azure Vision 2020 for tourism, Green Morocco Plan for agriculture, the Plan Halieutis 2020 for the fishing industry, Morocco Plus Export for exports, the Emergence Plan (2005) for industry followed by the national Pact for Industrial Emergence, 2009-2015 and the new Industrial Acceleration Plan, 2014-2020.

For example, to support the new industrial Acceleration Plan, the government earmarked a grant a financial support of approximately $2 \%$ of the GDP over 6 years. The government has also offered ad hoc support to attract the foreign investors into large private projects likely to generate significant positive externalities. An example is the project to set up a Renault Company plant in Tangier which targets to producing and to export 400000 cars per annum (World Bank, 2017).

\subsection{Sectorial Strategies and Plans with the Mitigated Results}

\subsubsection{Agricultural and Fishing Sectors}

Agriculture has always been the subject of close attention from governments in Morocco, owing among other 
reasons to its relationships with other sectors, its importance in foreign trade and its role in providing foodstuffs in rural and urban areas. Indeed, agriculture accounts for 15 to $20 \%$ in GDP and employs $44 \%$ of the labor force. If we add food processing, its contribution to GDP and employment amounts to $15 \%$ and $50 \%$, respectively (HCP, 2018). In this important sector, the Morocco Green Plan, launched in 2008 aiming at the modernization of Moroccan agriculture led to investments of approximately 3.7 billion dirhams on average per annum during a decade (totaling nearly 41 billion dirhams to date). However, Moroccan agriculture suffers from low productivity, low yields and high logistics, and production costs. For these reasons, agriculture has enjoyed tax exemptions to encourage and promote private and foreign investments. Nevertheless, the tax advantages became a source of distortions and inefficient allocation of investments and resources toward this sector (Karim, 2015).

As regards the fisheries sector, significant progress has been made in achieving the objectives set out in the Halieutis plan launched in 2009, as evidenced by the achievement of the objective of $96 \%$ of fisheries covered by rational management measures, the strengthening of fishing and marketing infrastructure and the improvement of the value of sea products. All of these efforts have helped to increase national fisheries production and boost Moroccan exports of fish products, recording an average annual growth rate of $6 \%$ since 2000 .

\subsubsection{Industrial Sectors}

Until 1990, the industrial sector was marked by a strong concentration on traditional industries today is characterized by a duality between traditional sectors such as textile-clothing in the search of a new repositioning, and new specializations in emergence such as in automotive and aeronautics industries, the food industry, the metallurgy and pharmaceutical industry. With the implementation of Industrial Acceleration Plan, 2014-2020 the industrial sector would be given a boost.

It should be noted that the Industrial Acceleration Plan, 2014-2020 has succeeded in attracting several leading industrial groups and contributed to improved product quality. By 2017 the share of exports with fairly high technological contents accounted for 55\%, 17 percentage points higher than 2007.

To support the industrial strategy, the Moroccan government has allocated 7.2 billion dirhams for period 2015-2018. This amount was used for the industrial development fund, training of human resources and land mobilization

Until now the industrial strategy has not had the expected re-industrialization effects. This is because an industrialization strategy cannot be reduced to sectorial support policies alone, but must also be based on cross-cutting policies that create a fertile environment for all actors. Moreover, the objective of increasing manufacturing value added to $23 \%$ of GDP by 2020 and creating 500000 jobs over the period 2014-2020 seems unrealistic given that industrial value added does not exceed $2.5 \%$ annually.

A parallel and complementary growth trajectory supported by "the positive distortion" of investment emerged and can be accelerated by the trade and the investment in the services. The country will become the first car manufacturer of Africa from here 2020 due to the French and Chinese FDI, together with the projected development of clusters of aeronautics, fertilizers and the textile. The challenge consists in integrating local SME in the value chains of these industries.

Given some positive sectoral dynamics, it is worth analysing why the industry as a whole continues to make a small contribution to job creation across the country. In 2016, the industry sector as a whole created 8000 jobs. In contrast, during the period 2009-2014, more than 130000 net jobs were lost.

The ongoing re-structuring of the industrial sector is creating jobs in new export activities, but on average more jobs are being lost over time in traditional labor-intensive industries. The net negative effect of these movements on employment is pronounced even more for the unskilled workers, because new employment is more demanding in terms of level of qualification (in a factory of wiring, the average worker has the baccalaureate). It is possible that this situation develops in a more favorable direction in the future (Ministry for the Economy and Finances, 2015).

The impulse given by this industrial policy starts to bear some fruits in certain niches, in particular in the sectors of the car and aeronautics. The installation in 2011 in Tangier of a large scale factory by the Renault manufacturer (with an output of 400000 cars per annum) played a role of engine of growth while attracting in its wake many suppliers of equipment. In 2018, the contribution of the car industry, in the total added value remained weak and did not exceed $2 \%$. But the expansion of the industry should still proceed, following the advertisement, since 2015, of the installation of a factory of the Peugeot-Citroen group.

Thus, since 2014, the car became the first exporting sector of Morocco and weighs with height of $20 \%$ in total 
exports of the country. But the industry is also subject to vulnerabilities. For [instance, owing mostly to falling demand associated with the COVID-19 pandemic], the car industry envisages a fall of $20 \%$ to $25 \%$ in activity in 2020, compared to that of 2019. In 2019, the export sales of the car industry was approximately 80 billion dirhams. Before the onset of the COVID-19 pandemic the sector planned to generate between 110 and 120 billion dirhams, by 202. Because of the ongoing pandemic this objective was significantly revised downwards. The car industry hopes from now on to reach the 100 billion dirhams only by 2022 (Ministry of Industry and trade, 2019).

The establishment of industrial investment funds provides incentive to the Moroccan investors for joining the industrial sector. The investment funds which exist today require mature companies which are not numerous in Morocco. There is need for investment funds tailored to specific sectorial investment needs and with less stringent access criteria.

An encouraging evolution is observed in the aeronautical pole established near Casablanca, around engines such as the groups Bombardier, Safran and Boeing. The impact of these investments are substantial in terms of employment (85000 in the automobile niche and 11000 in the aeronautical niche), as well as in exports. Today, more than 140 companies operate in aeronautics in Morocco. The sector employs 18000 people and the annual sales turnover to export turns around 18 billion dirhams.

The Moroccan aeronautical platform is recognized in the whole world by its capacity to be produced and by its competences. It is nevertheless necessary to improve and develop new technologies. The aeronautics industry has an integration rate of $38 \%$ at the beginning of 2019 .

Similarly, for the Renault project, which has enabled national automotive production to rise to nearly 345000 vehicles in 2016 and to create 7100 direct jobs, are not strong and not sufficiently numerous to have a macroeconomic impact on growth.

The "MMMs" (New World s Careers of Morocco), but also other sectors, could, moreover, also benefit, targeted actions by the State towards activities deemed to be priorities in terms of know-how and technologies, as well as a better involvement of Moroccan investors (CESE, 2019).

In the mining industry the phosphates sub-sector witnessed a major transformations over the last two last decades. The target for the sector, as established in the 2018 strategic plan, is to consolidate the leadership of Morocco on the world and continental market by doubling the mining capacity of Group OCP (Note 3 ) and to triple its capacity of phosphate processing by 2027.

\subsubsection{Renewable Energy Sectors}

Morocco has abundant wind and solar resources whose valorisation policy could offer important opportunities for growth and job creation. According to a report by Dii (2013), the wind, photovoltaic and concentrated thermo-solar industry sectors could represent up to 5\% of GDP in 2030 if the country invested enough - in partnership with international companies, whose expertise in the field of renewable energy is demonstrated - in electricity production of renewable origin.

Moreover, by diversifying its sources of supply, Morocco could reduce its dependence by half by in relation to imports of fossil fuels. These could pass from around $8 \%$ of GDP at present to $4 \%$ in 2030, thus considerably lowering the energy bill.

\subsubsection{Services Sectors}

Compared to what it was in 1999, investments in tourism sector, almost trebled Morocco hotels capacity. Tourist arrivals have reached 12.3 million in 2018, from 1999 to 2018 making Morocco the first African destination and the second in the Arab world. Morocco also plans to maximise the socio-economic spin-offs of the tourist strategy (vision 2030) through the creation of diversified and competitive tourist poles across the country.

In the area of transport and logistics which constituted a national priority to support economic activity, several projects were launched during these two last decades focused on roads, highways, ports and airports. The total public investment whose volume increased from 32 billion dirhams in 2005 to more than 66.6 billion dirhams in 2018 (equivalent for 6\% of GDP).

About the digitalization of the economy, their fast evolution in Morocco has followed the considerable development of new information technologies in recent years. According to figures revealed by the Digital Report 2020, 59\% of the world's population had access to the internet by the end of 2019. Morocco is well above the continental and even global average. Indeed, $69 \%$ of Moroccans will have access to the internet by the end of 2019, i.e. 2.9 million more people than a year earlier. In addition, $49 \%$ of Moroccans use social networks, a 
figure equal to the world average. $36 \%$ of this population is under the eligible age to use them. Moreover, in the latest report of the European Center for Digital Competitiveness, entitled Digital Riser Report 2020, Morocco ranks 4th in the MENA region in terms of digital competitiveness.

The process of digitalization gave place to the birth of the artificial intelligence, Cloud and the analysis of the mega-data (CMC, 2019). The digital technology offers immense potential to enable new modes of development and to help individual countries and individuals access the global stock of knowledge. The development of digital has a considerable impact on the social model of Morocco. Indeed, of new uses are appearing, as well as new problems. It is therefore imperative to ensure that we reap the benefits of the revolution. However, while access to the Internet and the use of the social networks are recording an "explosive" evolution, important efforts remain to be deployed to enable digital devices to play an energetic role in the employment of young people.

Morocco currently is in the category of the "countries of transition". For this category, the level of wise of technology is relatively high. It is thus necessary to fill the numerical gap to draw advantage from opportunities which offered by the related Internet and technologies.

The offshoring sector has been encouraging as it has led to the creation of jobs, equivalent to 69000 directs jobs between 2014 and 2018 in particular, since the signature of the performance plan, 2016-2020 dedicated to the sector. Within the framework of this plan, Morocco managed to attract nearly $80 \%$ of the world's top ten companies specialized in data-processing engineering.

The Morocco bank and financial sector experienced significant developments throughout the last two decades thanks to reforms which reinforce its robustness and its impact. The volume of bank credit to the economy to represent an average more than $90 \%$ of the GDP during the period of 2008 to 2018, after an average of 54\% between 2000 et 2007.

In total, the Moroccan financial system works effectively to mobilize the national saving, however it is quite weak in allocating them to the most productive activities. The causes include objective prudential constraints related to the risk of concentration subjective risk aversion by the commercials banks. According to the Doing Business 2020, Morocco ranks 112th on the on the ease of access to credit.

\section{Propagation of Shocks and Key Sectors in Input-Output Analysis-A Literature Review}

The modern global economic system is a highly interlinked network composed of several heterogeneous industries connected within and across different countries by means of input-output trade linkages. Several studies pointed out that the structure of this production web is crucial in establishing whether and how microeconomic local shocks can propagate throughout the economy and lead to significant aggregate fluctuations (Carvalho, 2014). Therefore, understanding the structure of this production network is of a foremost importance to design predictive tools and better inform regulators on how to dampen aggregate variability and reduce the likelihood of systemic risk.

Since the contributions of Leontief (1936) and Hirschmann (1958), the idea of input-output linkages as a key channel through which shocks propagate throughout the economy has been explored mainly in the real business cycle literature (e.g., Horvath, 1998, 2000; Long \& Plosser, 1983; Shea, 2002). Recently, several papers have revisited the argument, proposing new approaches and perspectives (see Roson \& Sartori, 2016 for a wide review). For example, Gabaix (2011) finds that the distribution of firm size in an economy is typically fat-tailed. A degree distribution is fat-tailed when there are only a few industries which have several connections to many other industries. Hence, any shock affecting these central sectors would be able to propagate and generate macrodisturbances. Under these circumstances, the central limit theorem breaks down, and idiosyncratic shocks to large sectors or firms affect aggregate outcomes. Building on Gabaix's (2011) "granular" hypothesis, Carvalho and Gabaix (2013) interpret the recent rise of macroeconomic volatility as a direct consequence of the increase in the size of the financial sector. Further important theoretical contributions in this direction were made by Acemoglu et al. (2012), Acemoglu, Akcigit, and Kerr (2016), Acemoglu, Carvalho, Ozdaglar, and Tahbaz-Salehi (2017), Carvalho (2014) and Carvalho, Nirei, Saito, and Tahbaz-Salehi (2016), who focused on the impact the topology of the economic network has on shock propagation. In particular, in their seminal work, Acemoglu et al. (2012) find that the existence of relatively few, "dominant", suppliers of intermediate factors fosters the amplification of sectoral shocks. The authors propose to interpret the input-output structure as a (weighted) network, where the nodes correspond to the sectors and the links to the input-output trade flows. In such a framework, the relative importance of an industry as a supplier for other industries is captured by the sum of weights of all outgoing links, that is what is known in network theory as the weighted degree or strength of a node. Studying the distribution of degrees in the economy and the "fat-tailedness" of that distribution, Acemoglu et al. (2012) conclude that the asymmetric and fat-tailed distribution of the input-output network connections 
serves as the micro-origin of the macroeconomic fluctuations.

Most of the empirical works in this field focused on a single national economy, whilst much less attention has been given to the cross-country transmission of shocks, which is crucial from a Brexit perspective. However, there are exceptions. For example, Alatriste-Contreras and Fagiolo (2014) investigate how economic shocks propagate through the input-output network connecting industrial sectors in Europe. They show that the more a sector is globally central in the country network, the largest its impact. Similar results are stressed by the recent and growing literature on trade in value added and its implication on the transmission of shocks via international trade (e.g., see Garbellini \& Wirkierman, 2014; Johnson \& Noguera, 2012; Nagengast \& Stehrer, 2016 and Tukker \& Dietzenbacher, 2013, among others). Building on this literature and on Gabaix (2011), Di Giovanni and Levchenko (2012) and Eaton, Kortum, and Sotelo (2012) show that international trade amplifies the "granularity" of an economy and hence its sensitivity to sectoral shocks.

The common theme across the literature reviewed is that whenever few hubs dominate the linkage structure in the economy, an idiosyncratic shock which hit these hubs will result in sizable aggregate fluctuations. Therefore, from a Brexit perspective, it is of primary importance to study the structure of the European production network (EPN), finding out if key sectors exist and identify them in order to understand which sectors should be safeguarded. Further, a key sector analysis would allow policymakers to better understand which sectoral tariffs would have a more distortive impact.

To date, many studies have been conducted on the economic impact of Brexit (see the special issue edited by McCann, 2018, and the recent mini-symposium edited by Greenaway \& Milner, 2019, among others). Just a few have emphasised the relevance of input-output linkages (e.g., Vandenbussche, Connell, \& Simons, 2017; Cappariello, Damjanovic, Mancini, \& Vergara Caffarelli, 2018; Chen, Los, et al., 2018). Nobody focused specifically on the analysis of the key sectors in the EPN. The present study aims to fill this gap in the literature.

The identification of key sectors in an economy has been one of the most important research topics in inputoutput analysis, for a long time (see Miller \& Blair, 2009; Temurshoev \& Oosterhaven, 2014 for a wide review). Since the seminal works of Rasmussen (1956), Chenery and Watanabe (1958) and Hirschmann (1958), this strand of input-output literature has often focused on the number, strength and structure of intersector linkages (Los, 2004; Yotopoulos \& Nugent, 1973). After the first introduction of the linkage measures, several changes have been proposed (Jones, 1976). For example, the eigenvector method of backward linkages proposed by Dietzenbacher (1992), which is based on the reasoning that industries with more linkages should be weighted more (Luo, 2013). This method is similar to the eigenvector centrality long used in network theory and social network analysis, according to which nodes are considered to be central in the network if their connections in the network are themselves well-connected nodes (see Alatriste-Contreras, 2015; García Muñiz, Raya, \& Ramos Carvajal, 2008, 2011 and Gurgul \& Lach, 2018 for a discussion on the similitudes between input-output linkage measures and network centrality measures). One drawback of the eigenvector method is that it does not penalise the distant connections (Newman, 2010). Therefore, its variations such as Katz-Bonachic centrality (Bonacich 1987; Katz, 1953) and PageRank centrality (Brin \& Page, 1998) have been preferred in recent studies on inputoutput networks (Acemoglu et al., 2012; Carvalho, 2014; Cerina, Zhu, Chessa, \& Riccaboni, 2015).

All these measures generally identify the key or strategic sectors in the network. However, focusing on Brexit as a trade shock, we are mainly interested in the input-output trade connections between the UK and European countries.

\section{Methodology for Selection of Sectors with Potential for Accelerate Growth and Investment}

To select sectors with best opportunities for accelerated investment and growth we started with an initial list of 20 sub-sectors (see below), and applied a methodology based on production and employment multipliers of the sectorial uses of the final demand of the Moroccan economy, employment elasticities of growth, sectorial contribution in the total added value, the productivity of labor, the sector contribution to total exports, and the foreign investments attracted during the two periods 2007-2012 and 2013-2018.

\subsection{Multipliers Approach}

The multipliers of the final demand constitute a traditional application of the input-output theories of Wassily Leontief. In the current application, a series of Morocco input-output tables at constant prices (Note 4), for the years 2007, 2012 and 2018 were used to estimate the impact changes in one or the other component of the final demand (variations of the public expenditure, the investments, exports...). They represent the ratio of the total effects of a change of the final demand, brought back to the initial effects of this change.

The multiplier shows the production (or employment) effect in the sector concerned where the investment is 
made (direct effect), and the production (or employment) effect generated in the other sectors related to it (indirect effect). The sum of the both effects of production or employment, is the only one considered and interpreted in this analyze inputs-outputs.

It's noted that the production multiplier of demand in the Moroccan economy has fallen from 1.74 in 2007 and 2012 to 1.58 in 2018 . That means that in 2007 the production of the whole of the economy, on average, increased by 1.74 million dirhams in response to an increase of a one million dirhams of the final demand, and that this effect reduced to 1.58 million in 2018. Figure 4 below shows the output and employment multipliers in 20 sub-sectors of the economy.
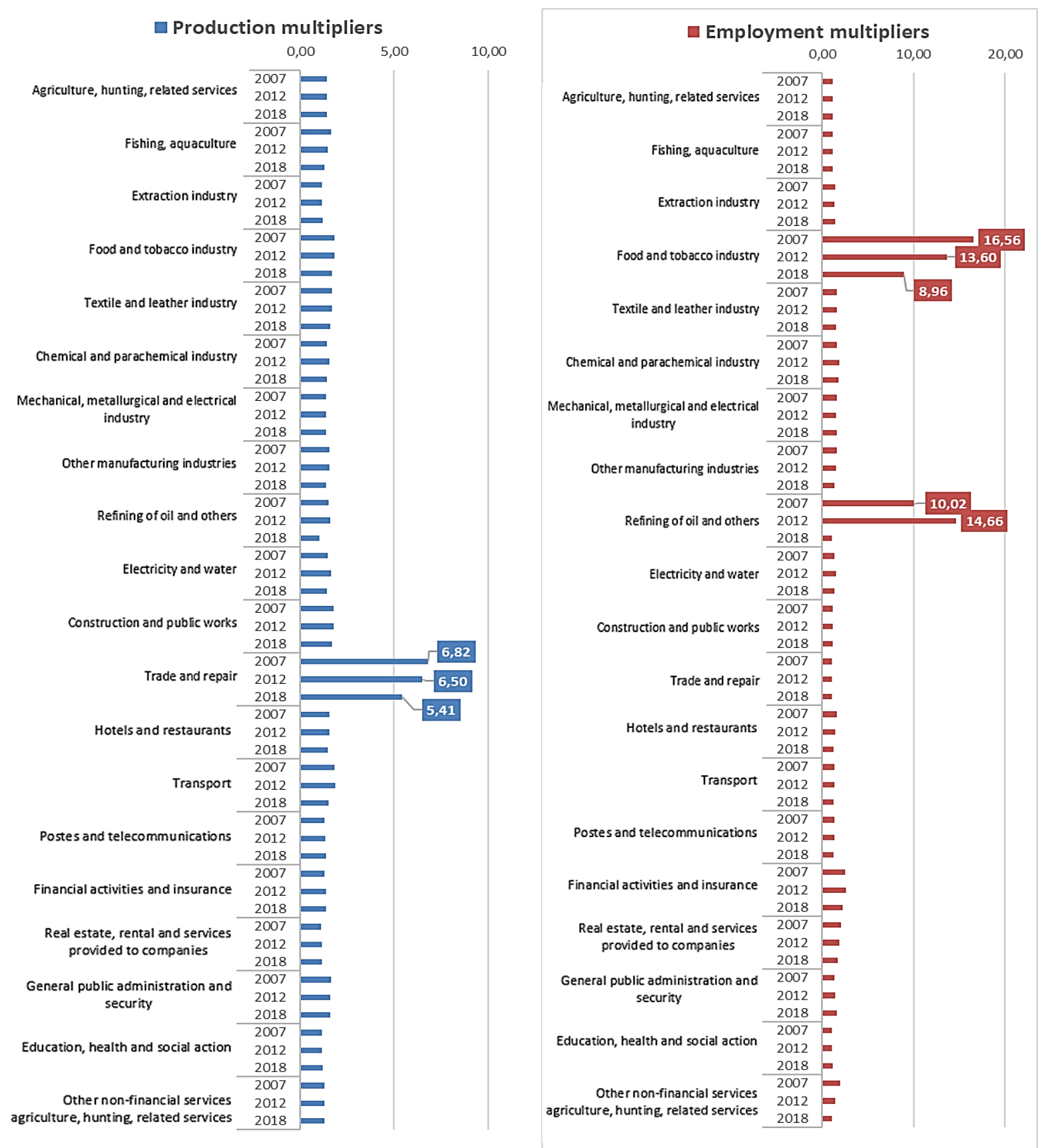

Figure 4. Multipliers of production and employment by sub-sector, IO 2007, 2012 and 2018

The sectors with highest output multipliers are trade and repair and food industry and those with the highest employment multipliers are food industry and financial activities and Insurances, and based on this the following sectors: Trade, food industry and financial sector. 
The employment multipliers are used to estimate the importance of a branch of activity in terms of employment. The employment multiplier for the year 2007 recorded 2.70 million jobs created in the economy, directly and indirectly via the chain of the suppliers, following an increase in final demand of one million of dirhams. In 2012 and 2018, 2.75 million and 1.77 million jobs were created respectively in the economy.

The coefficient of employment is the reverse of the labor productivity, and constitutes the principal determinant of the employment multiplier. It makes it possible to explain why several very labor intensive industries such as food processing like agro-alimentary industry, the refining of oil in the past, the activities financial and insurances and the real estate hiring and services to companies post the highest employment multipliers.

The financial activities and the real estate have high employment multipliers but the weakest output multipliers in the economy, while the real estate sub-sector has high output multipliers and one of the weakest employment multiplier.

Sectors not exposed to international competition (real estate, trade and services) could widen their profit margins by adjusting their prices upwards in response to growth in domestic demand and expansion of credit. Certain public programs amplified this phenomenon, by granting advantages and subsidies to these sectors. In the real estate, the tax incentives granted the promoters of social housing in particular reached $1 \%$ of the GDP, which attracted a large number of investors into the sector (Ministry for the Economy and Finances, 2015).

This difference in profit margins between protected and exposed sectors is reflected in the trend of prices of the added value. Since 2007, the price of the value added value in the textile and clothing sub-sector did not experience any increase, whereas that of the construction sector increased by $50 \%$ and that of the hotels, and restaurants and trade increased by $60 \%$. In this context, the operators, in particular investors, rationally decided to withdraw from the exposed sectors of the economy towards the protected ones where the benefits were sure in the short term.

In addition to focusing on attracting FDI Morocco should also direct efforts to creating an endogenous growth dynamics based on Moroccan business actors to ensure sustainable national industry development [as this would also strengthen the country's ability to absorb the development impetus that can be brought by foreign partnerships].

Moreover, the input-output table for 2018 the automobile reveals itself as a driver of other industry branches. The rate of integration of the automotive sector [with other industries] is to $55 \%$ with an objective of $80 \%$, with an integration engine and an integration upstream going to the raw materials these world trades represent a sector of investment for the Moroccan capital.

\subsection{Employment Elasticities Approach}

The strongest employment responses to sector output growth are observed in banking, insurances, real estate, agriculture, forestry, fishing and some branches of manufacturing industries. Other sectors such as building, hotels and restaurants lost some of their employment potential to the point of experienced experiencing negative employment elasticities.

From these review of the two indicators (multipliers and employment elasticities) that the sectors with the greatest employment potential are not necessarily those which create have greatest growth potential. This is for instance the case of food industry or the real estate. 




Figure 5. Elasticities per sub-sector, 2007-2012 and 2013-2018

\subsection{Satisfactory Attrativity of the FDI}

It should be noted that the Morocco's attractiveness to FDI reflects the progress that the country has made in 
improving its general business climate. indeed, FDI net inflows to Morocco, have consolidated by $36 \%$ to total 3.6 billion dollars into 2018. As a result, Morocco ranks fourth in Africa in terms of hosting FDI, just behind Egypt, South Africa and Congo. In terms of geographical origin, Ireland is now the largest investor in Morocco, with a share of $20 \%$ of the total FDI, after 10\% in 2017 ahead of France, which comes in second place with a share of $17 \%$ against $23 \%$ in 2017.

Multiple instruments were deployed to attract foreign investors, in particular the establishment of modern industrial parks ("integrated industrial platforms"), the provision of tax incentives, direct subsidies, advantageous financing terms and training support. This effort [which started back in YYY] continued with the adoption, in 2014, of the Industrial Acceleration Plan (PIA) which reinforces the existing system by Industrial Development and Investments Funds (with an envelope equivalent to $2 \%$ of the GDP over the period 2014-2020) in order to grant subsidies to selected industry branches, a new investment code, and the installation of industrial ecosystems having vocation to create a new dynamics and a new relation between large industrial groups and Small and Medium Enterprises (SMEs).

The Real estate, Banking and insurance, tourism, energy and mines sectors attracted the bulk of FDI since 2007. On the contrary, agriculture and fishing, transport, education and skills development attracted little foreign investors' interest.

Beyond of the need to strengthen the agricultural and the food industry or trade, $t$ [there seems to be strong] strong evidence in favor of the importance of the industrial sector and in particular its exporting branches to ensure a deeper, broader and more durable integration in the international value chains through in particular a stronger sophistication, technological content of the country's exports (CESE, 2019).

\subsection{Output Diversification}

Amidst falling growth in global trade, Moroccan exports continued their strength in 2018, increasing by $10.6 \%$ against $10.3 \%$ in 2017. This was accompanied by a diversification of the product and market space. The number of export markets increased by 1.4\% on average annual between 2007 and 2018, (from 149 to 185 markets), and the number of exported products increased by 1.6\% on average annually between 2007 and 2018 (2580 to 3405 products). The change in the composition of Moroccan exports favored the industrial branches with strong value added (automotive, electric...), at the moment when the traditional exporting sub-sectors (clothing, agricultural), saw their weight reduced appreciably.

The sub-sectors of agriculture, the mechanical engineering industries and other manufacturing industries of electricity and water, other non-financial services experienced high average annual growth rates between the two periods: 2007-2012 and 2013-2018.

\section{Results of the Input-Output Analysis}

The weak economic growth is related to the development of protected sub-sectors.. A large proportion of Moroccan companies' profits come from very high margins compared to others in the area, which suggests that these companies are confronted with less high levels of competition. Indeed, of many local companies operating in sectors that exhibit profit benefit from tax exemptions (real estate, trade, agro-alimentary industry) or high tariff protection (consumer goods), which contributes to high margins and the search of revenues which reduce the investments in more competitive and tradable sectors and block the diversification and the creation of jobs (Achy, 2013).

This is confirmed by a study of the Royal Institute of the Strategic Studies that note that protection, by reducing competition, allowed the appearance of monopolistic rents. Profitable companies benefitted from abnormally high prices and excess profits, not from investment in competitiveness in product quality and the incorporation of new techniques, but to perceive excessive profits (IRES, 2014). Deepening the reforms by opening the markets to more competition, allowing new economic actors to dispute these markets, is necessary as those that have been carried out have had limited impact.

\subsection{Towards a Revival of the Moroccan Development Model}

In 2019, the King of Morocco established a special subcommittee charged with working out a new development model for the country and defined contours of this new model according to a participative and inclusive approach. The current growth model of Morocco allowed a certain sophistication of the trade in goods thanks to the better infrastructure, but the country's presence in the international value chains and the added value on its products is still weak and the concentration on the European market is high. The emergence of new industries (automotive, aeronautics, and electronics) is encouraging, insofar as these sectors are traditional axes of growth drawn by the productivity. The Moroccan presence in these emerging sectors is however still weak and 
international competition is wild. In the future, the strategic initiatives of Morocco trade investment with the EU and sub-Saharan Africa should contribute to reinforce its external competitiveness.

With a model of development more centered on competitive markets and the broader development of the private sector, the position of Morocco between Europe and Africa and the growth of the infrastructures could be transformed into decisive competitive advantages for the country (Karim et al., 2018).

To ensure diversification, this structural transformation should touch sectors such as agriculture, industry or the services. Modernization of agriculture will have to accelerate ,starting with its digitalization and with strongly developing the valorization of its products through a competitive and integrated agro-industrial fabric, covering the whole of the territories. This will not be possible unless there is massive access of the small farmers to training and access to new technique of production (CESE, 2019).

\subsection{The Dynamism of the Private Sector}

To create the conditions for the emergence of a dynamic and diversified private sector, able to create the jobs which Morocco needs urgently, and competitive markets should be permitied to exist. The currently limited dynamism of the Moroccan private sector (ADB, 2014) can be related to: (i) the significant weight of the informal sector which represents $40 \%$ in the economy, (ii) large share of SME and their inability to grow larger, (iii) the limited share of the private sector in total investment, (iv) the weak sectorial diversification of the investments, and (v) the limited surge of the foreign direct investments, carrying modernity and dynamism.

The lack of dynamism of the private sector impedes the structural transformation of the economy and the benefits of productivity which are generally associated with the growth and the creation of decent employment.

\subsection{Proposed Sectors for Investors and Technical and Financial Assistance}

From previous analyses conducted in terms of the Inputs-outputs model, employment elasticity values and the degree of attraction of foreign direct investment and export diversification, we identify four dynamic sectors: trade, banking and insurance, food industry and renewable energy.

It is therefore a question of going deeper into the search for growth. We must, in fact, do the following contribute more significantly to a much larger number of actors and succeed thus a real structural transformation of the Moroccan economy.

With a view to diversification, this structural transformation should affect trade, banking, agriculture, agro-industry and renewable sectors. These sectors will be called upon to accelerate their modernization, via their digitalization and to strongly develop the valorization of their products and services. This cannot be achieved through massive access to training and new technologies.

Beyond the strengthening of the five sectors, the consensus is very broadly shared on the paramount importance to be given to the industrial sector and in particular to export (CESE, 2019).

\subsection{International Organizations and Donors Which Support the Sectorial Projects in Morocco}

A significant number of international organizations supports and stimulates the development of the economy. Two principal sources of international financing can be distinguished: (i) International financial Institutions likely to provide a support to the structuring, financial engineering necessary for the infrastructure projects, in particular through the recourse to the public-private partnerships (PPP); and (ii) International Donors likely to be mobilized to support the technical assistance (studies of pre-feasibility), and to strengthen capacities in both the private and public sector.

Currently the principal IFIs supporting Morocco are the World Bank Group, the German Bank for the Development (Kreditanstalt für Wiederaufbau, KfW), the International Finance Corporation, the Multilateral Investment Guarantee Agency of, the French Development Agency, the Islamic Development Bank, the African Bank of Development, the European Investment Bank, and the European Bank of the Rrebuilding and Development.

The principal donors and the agencies of bilateral co-operation with Morocco are as Funds World for Environment (FEM); European Union; Deutshe Gesellschaft for International Zusammenarabelt, Japanese International Cooperation Agency; Belgian Development Agency; American Agency for the International Development; The Management of the development and the Swiss co-operation; Program of the United Nations for Development; Program of the United Nations for Environment; and French Environment and Control of Energy Agency. 


\section{References}

African bank of Development. (2014). Diagnosis of growth of Morocco: Analyze constraints with a broad and inclusive growth (p. 55).

Carnegie Endowment for International Peace. (2013). Economie de la rente en 3 questions. Achy L. SMEA.

CNUCED. (2018). Rapport sur l'investissement dans le monde et les nouvelles politiques industrielles: Repères et vue d'ensemble.

Conseil Economique et Social et Environnemental. (2019). Le nouveau modèle de développent du Maroc.

Debbarh, A. M. (2006). L'énergie: Développement énergétique au Maroc depuis 1955, perspectives 2025. Rabat, HautCommissariat au Plan, non publié.

Dii. (2013). Les énergies renouvelables au Maroc: Un secteur porteur de croissance et d'emplois. Rapport présenté à Casablanca, 22 mai.

Federal office of the Plan. (2013). Multipliers of production, income and employment 1995-2005: An analysis input-outputs at constant prices. Working paper 8-13.

Haut Commissariat au Plan. (2016a). Etude sur le rendement du capital au Maroc. Rencontre sur le rendement du capital physique au Maroc, 13 janvier 2016.

Haut Commissariat au Plan. (2016b). Maroc en chiffre. 2007 à 2019.

Institut Royal des Etudes Stratégiques (2019). Vers un nouveau modèle de développement. Rapport d'activité $2019 / 2020$.

Institut Royal des Etudes Stratégiques. (2014). Industrialisation et compétitivité globale du Maroc.

Institut Royal des Etudes Stratégiques. (2017). Transformation numérique et maturité des entreprises et administration marocaine (p. 60).

Karim, M. A. M. (2015). Taxation of Moroccan agriculture: an analysis of the sensitivity of the results of a dynamic computable general equilibrium model. Middle East Development Journal, 89-107. https://doi.org/10.1080/17938120.2015.1019294

Karim, M. H. El K. (2018). Impact of Morocco ECOWS Economic relations on economic growth in morocco. An analysis using ARDL model. International Journal of Economics Finance, 10(5). https://doi.org/10.5539/ijef.v10n5p105

Ministère de l'Economie et des Finances, DEPF. (2019a). Note de conjoncture économique.

Ministère de l'Economie et des Finances, DEPF. (2019b). Synthèse du Rapport Economique et Financier accompagnant le projet de Loi de Finances 2020.

Ministère de l'Economie et des Finances, DEPF. (2020). Perspectives économiques en 2020 dans le contexte de la crise COVID.

Moroccan Economic Center (CMC). (2018). Digitalization: Which impact on the Moroccan companies? Monthly review "Morocco Economic situation".

OCDE. (2018). Examen des statistiques d'investissements directs internationaux au Maroc. Programme Maroc pays.

Office of the High Commission in the Plan, HCP. (2016). Study on the Output of the Physical Capital in Morocco. Note published on the site of the HCP.

World Bank Group. (2017). Morocco by 2040. To invest in the immaterial capital to accelerate economic emergence.

World Bank Group. (2019). Tally of Partnership-Country for the Kingdom of Morocco over the period 2019-2024. Middle East area and North Africa.

World Bank Group. (2020). Doing Business 2020 comparing business regulation in 190 economics. 


\section{Appendix}

Appendix 1. Multipliers of production per sub-sector, Input-Output 2007, 2012 and 2018

\begin{tabular}{lllll}
\hline Codes & Sub-sectors & 2007 & 2012 & 2018 \\
\hline G00 & Trade and Repair & 6,82 & 6,50 & 5,41 \\
D01 & Agro-alimentary Industry and Tobacco & 1,84 & 1,83 & 1,70 \\
I01 & Transport & 1,81 & 1,88 & 1,52 \\
F45 & building & 1,78 & 1,76 & 1,67 \\
D02 & Industry of the Textile and Cooking & 1,69 & 1,70 & 1,59 \\
B05 & Fishing & 1,64 & 1,48 & 1,30 \\
L75 & General Public Administration and Safety & 1,64 & 1,59 & 1,59 \\
H55 & Hotels and Restauration & 1,56 & 1,55 & 1,48 \\
D05 & Other Industries Manufacturieres & 1,56 & 1,56 & 1,40 \\
D23 & Oil Refining And Otherrs & 1,52 & 1,60 & 1,00 \\
E00 & Electricity and Water & 1,47 & 1,64 & 1,42 \\
D03 & Chemical and Parchemical Industry & 1,44 & 1,55 & 1,44 \\
A00 & Agriculture, Drives Out, Ancillary Services & 1,41 & 1,44 & 1,41 \\
D04 & Mecanic, Metallurgic and electric Industry & 1,37 & 1,37 & 1,36 \\
J00 & Financial Activities and Insurances & 1,31 & 1,36 & 1,39 \\
OP0 & Other non financial services & 1,30 & 1,30 & 1,27 \\
I02 & Posts and Telecommunications & 1,27 & 1,32 & 1,40 \\
C00 & Industry of The Extraction & 1,17 & 1,13 \\
MN0 & Education, Health and Social Action & 1,14 & 1,17 \\
K00 & Real Estate, Hiring and Servicers to the Compagnies & 1,13 & 1,13 \\
\hline
\end{tabular}

Appendix 2. Multipliers of employment, Input-Output 2007, 2012 and 2018

\begin{tabular}{llccc}
\hline Codes & Sub-sectors & 2007 & 2012 & 2018 \\
\hline D01 & Agro-alimentary Industry and Tobacco & 16,56 & 13,60 & 8,96 \\
D23 & Oil Refining And Otherrs & 10,02 & 14,66 & 1,05 \\
J00 & Financial Activities and Insurances & 2,52 & 2,59 & 2,26 \\
K00 & Real Estate, Hiring and Servicers to the Compagnies & 2,10 & 1,92 & 1,72 \\
OP0 & Other non financial services & 2,00 & 1,47 & 1,08 \\
D03 & Chemical and Parchemical Industry & 1,66 & 1,92 & 1,85 \\
H55 & Hotels and Restauration & 1,61 & 1,40 & 1,30 \\
D02 & Industry of the Textile and Cooking & 1,60 & 1,60 & 1,50 \\
D05 & Other Industries Manufacturieres & 1,59 & 1,49 & 1,35 \\
D04 & Mecanic, Metallurgic and electric Industry & 1,59 & 1,56 & 1,63 \\
C00 & Industry of The Extraction & 1,47 & 1,35 & 1,46 \\
L75 & General Public Administration and Safety & 1,39 & 1,47 & 1,63 \\
E00 & Electricity and Water & 1,37 & 1,55 & 1,38 \\
I02 & Posts and Telecommunications & 1,34 & 1,32 & 1,29 \\
I01 & Transport & 1,33 & 1,32 & 1,25 \\
F45 & Building & 1,21 & 1,15 & 1,14 \\
A00 & Agriculture, Drives Out, Ancillary Services & 1,20 & 1,20 & 1,18 \\
B05 & Fishing, Aquiclture & 1,18 & 1,13 & 1,15 \\
G00 & Trade and Repair & 1,12 & 1,11 \\
MN0 & Education, Health and Social Action & 1,08 & 1,11 & 1,09 \\
\hline
\end{tabular}


Table 1. Elasticities of employment per sub--sector, 2008-2012

\begin{tabular}{|c|c|c|c|c|c|c|c|}
\hline Sub-sectors & 2008 & 2009 & 2010 & 2011 & 2012 & $\begin{array}{c}\text { Average } \\
2008-2013 \\
\end{array}$ & \\
\hline Textile industry, leather & 0,21 & $-16,09$ & $-8,76$ & $-2,79$ & 3,66 & $-4,76$ & \multirow{5}{*}{$\varepsilon<0$} \\
\hline Trade and repair & 0,10 & $-0,55$ & $-2,38$ & 0,24 & 0,34 & $-0,45$ & \\
\hline Activities not indicated & 4,69 & $-4,46$ & 0,69 & 1,62 & $-4,03$ & $-0,30$ & \\
\hline General administration & $-0,64$ & 0,18 & $-0,46$ & 0,30 & 0,07 & $-0,11$ & \\
\hline Agriculture, forest and fishing & $-0,07$ & $-0,00$ & 0,12 & $-0,04$ & 0,50 & 0,10 & \\
\hline Social services provided to the community & 0,88 & 0,20 & $-1,27$ & 0,08 & 1,73 & 0,32 & \multirow{3}{*}{$0 \leq \varepsilon<0,5$} \\
\hline Food industry, drinks and tobaccos & 0,84 & 0,09 & $-0,14$ & 1,20 & $-0,01$ & 0,40 & \\
\hline Electricity, gas and water & $-0,37$ & 1,04 & $-0,35$ & 1,95 & $-0,16$ & 0,42 & \\
\hline Other manufacturing industries & 0,20 & $-1,03$ & $-0,11$ & $-0,19$ & 4,44 & 0,66 & \multirow[t]{3}{*}{$0,5 \leq \varepsilon<1$} \\
\hline Banks, insurances, businesses, provided services & 0,91 & 2,45 & 1,12 & 1,13 & 0,17 & 1,16 & \\
\hline Real estate & 1,00 & 3,99 & 1,33 & 0,29 & $-0,29$ & 1,26 & \\
\hline Mining & 0,04 & 0,29 & $-0,02$ & 0,50 & 6,23 & 1,41 & \multirow[t]{4}{*}{$\varepsilon>1$} \\
\hline Hotels and Restoration and trade & 5,25 & 0,79 & 0,93 & 7,61 & 0,17 & 2,95 & \\
\hline Transport, warehouses and communications & $-26,87$ & $-0,20$ & 2,16 & 33,43 & 14,37 & 4,58 & \\
\hline Total & 0,11 & 0,31 & 0,20 & 0,14 & 0,00 & 0,15 & \\
\hline
\end{tabular}

Table 2. Elasticities of employment per sub--sector, 2013-2018

\begin{tabular}{|c|c|c|c|c|c|c|c|c|}
\hline Sub-sectors & 2013 & 2014 & 2015 & 2016 & 2017 & 2018 & $\begin{array}{c}\text { Average } \\
2008-2013\end{array}$ & \\
\hline Trade and repair & 0,71 & 0,85 & $-448,72$ & $-0,81$ & $-0,61$ & 1,14 & $-89,72$ & \\
\hline Real estates & $-9,35$ & $-0,19$ & 1,86 & $-9,30$ & 4,16 & $-0,08$ & $-2,56$ & \\
\hline Transport, warehouses and communications & $-0,36$ & 0,05 & $-0,76$ & $-0,21$ & $-8,75$ & 4,95 & $-2,01$ & $\varepsilon<0$ \\
\hline General administration & $-0,49$ & $-0,19$ & 0,68 & $-1,11$ & $-0,87$ & 0,97 & $-0,40$ & \\
\hline Activities badly or not indicated & 0,14 & 0,85 & $-0,30$ & $-1,52$ & 0,49 & 4,41 & $-0,07$ & \\
\hline Electricity, gas and water & $-1,50$ & 1,35 & $-1,00$ & $-0,07$ & 1,03 & 0,93 & $-0,04$ & \\
\hline Mining & 1,46 & $-0,57$ & $-0,47$ & 0,46 & $-0,65$ & 0,26 & 0,05 & \\
\hline Textile industry, leather & 0,09 & $-0,04$ & $-0,05$ & 1,11 & $-0,86$ & $-0,40$ & 0,05 & $0 \leq \varepsilon<0,5$ \\
\hline Hotels, Restoration and trade & 0,29 & 0,60 & $-2,81$ & $-0,41$ & 3,38 & $-0,11$ & 0,21 & \\
\hline Food industry, drinks and tobaccos & $-1,37$ & 0,00 & 0,96 & 0,59 & 3,44 & 173,44 & 0,72 & $0,5 \leq \varepsilon<1$ \\
\hline Social services provided to the community & $-0,19$ & $-1,13$ & $-0,11$ & 2,02 & 4,19 & 3,10 & 0,96 & \\
\hline Real banks, insurances, businesses, provided services & 1,01 & 2,45 & 0,91 & $-0,62$ & 2,40 & 1,63 & 1,23 & \\
\hline Agriculture, forest and fishing & $-0,91$ & $-0,66$ & 0,76 & 2,55 & 5,73 & 0,30 & 1,49 & $\varepsilon>1$ \\
\hline Other manufacturing industries & 0,55 & $-0,62$ & 11,60 & 0,71 & 0,30 & 0,74 & 2,51 & \\
\hline Total & 0,23 & 0,13 & 0,06 & $-0,15$ & 0,10 & 0,26 & 0,08 & \\
\hline
\end{tabular}

Notes

Note 1. Study on the output of the physical capital in Morocco, HCP 2016.

Note 2. This ratio measures the effectiveness of the investment: a number of units of investment to produce an additional unit of the GDP.

Note 3. It is a public company that exploits, valorises and sells phosphate in Morocco

Note 4. We exploited inputs-outputs tables available for the years 2007, 2012 and 2018 published by the HCP, Morocco. The table relating to 2019 being always provisional. For the other data, we used official data of the HCP and Ministry for the Economy, Finances and the modernization of administration (DEPF).

\section{Copyrights}

Copyright for this article is retained by the author(s), with first publication rights granted to the journal.

This is an open-access article distributed under the terms and conditions of the Creative Commons Attribution license (http://creativecommons.org/licenses/by/4.0/). 